\title{
Misplaced Aggression in International Relations: A Personal Attack on the United States President in Iraq
}

\author{
Abang, Sunday Owen, $\mathrm{PhD}$ \\ Lecturer, Olabisi Onabanjo University, Ago-Iwoye, Ogun State, Nigeria.
}

\begin{abstract}
The attacks and frequent insurgencies in Iraq have affected the various systems put in place by the Iraqi government. The attack on President George W. Bush in Bagdad by an Iraqi journalist covering the event signified a violation of the right of sovereign immunity enjoyed by a President on invitation by his host - this type of behaviour is often referred to as 'misplaced' or 'redirected aggression. Also, the attack is centred on the right claim by US to wage wars of choice on the ground of threat to their interest. After agonistic encounters, observers view the rivalry as an individual attack on a third party that continues with policy that sparks up provocation in the past. That point to the inevitable problems that face a Great power when it tries to maintain or reshape the international norm of non-interference on the internal affair of states as a whole, for claim on fighting "terrorists"
\end{abstract}

Keywords: Aggression, Terrorism, War on terror, Freedom, Interest

\section{Introduction}

The rising anti-Americanism is driven almost exclusively by cumulative frustration and anger with the substance and style of America foreign policy in the area, and not by imagined opposition to basic American values of freedom, democracy, equality and tolerance"(Khouri,2002:2)

In the word of Khouri, the critics are not again America values such as democracy and equality- Arab spring acknowledge the values of freedom and tolerance for change, but those against the America policies does that because of her international policing of the entire world.

The event of misplaced aggression on President Bush of the United States of America on December 14, 2008 in Iraq presents a new tactics in the Middle East to confront opponents. An Iraqi journalist, Muntadar al-Zaidi, hurled his shoes at the visiting US President as he was addressing a news conference in Baghdad. One wonders at what the intention of Muntadar al-Zaidi could have been in carrying out that attack, and calling the US President "a dog"(The Guardian, December 23, 2008). The issue that causes the misplaced aggression was Bush policies that have placed suffering on the Iraq people.

We may want to ask what aggression actually is, and who is capable of committing aggression. All these questions deserve answers. Aggression is a substance used negatively by one actor against the other actors. This lead us to want to know if there is any distinction on how aggression is placed. The concept of aggression assumes that a distinction exists between good and bad conduct in international affairs. The implication of this distinction is that it must be committed by an aggressor.

From Wikipedia," the convention of January 31, 1934 defined an act of aggression as:

i) Declaration of war upon another state

ii) Invasion by an armed forces, with or without a declaration of war

iii) Naval blockade of the coasts or part of another state

Nation-states never gave in to the convention definition of act of aggression, now paving way to Article 39 of the United Nations Charter that provides that the UN Security Council shall determine the existence of any act of aggression and shall make recommendations, or decide what measures shall be taken in accordance with Article 41 and 42 to maintain International peace and security.

In 1950, the Nuremberg tribunal defined crime against peace in Principle VI (a):

i) As planning, preparation, initiation or waging of a war of aggression or a war in violation of International treaties, agreement or assurances.

ii) Participation in a common plan or conspiracy for the accomplishment of any of the acts mentioned under(1)

As at 1950 the United Nations has been battling with how to agree on the definition of aggression. But it was in 1974 that they finally agreed on how to coin the definition of aggression.

On December 14, 1974 UN General Assembly adopted resolution 3314 make a distinction between aggression (which give use to International responsibility and war of aggression (which is a crime against International peace). 
Act of Aggressions are defined as armed invasions or attacks, bombardment, blockades, armed violations of territory permitting other states to use one's own territory to perpetrate acts of aggression and the employment of armed irregular or mercenaries to carry out acts of aggression. A war of aggression is a series of act committed with a sustained intent. The definition distinction between an act of aggression and a war of aggression make it clear that not every act of aggression would constitute a crime against peace, only war of aggression does. Non-state parties like NATO and WARSAW pact than were outside the scope of the definition. Moreover, the definition does not deal with the responsibilities of individuals for acts of aggression" (cited from Wikipedia.).

Wilson (2009) maintains that aggression is the product of an agent act; the agent knows the behaviour contemplated is bad or wrong and intend to do it. The agent act of attack on the world trade centre in the US was referred as an act of terror by G.W. Bush.

The September 11, 2001 attacks on the America, US, promoted a new and aggressive campaign to combat "terrorism" worldwide. America and other states adopted counter-terrorism measures that "nations need not suffer an attack before they can lawfully take action to defend themselves against forces that present an imminent danger" (Bush, 2002,15).

In counterterrorism, the first building block of emerging world order fell into place. That is to say those new allies emerged with a broad international coalition against terrorism as President G.W. Bush made a strong pronouncement that any state that is not ready to fight "terrorists" is against the interest of peace. This statement caused countries to adopt the "bandwagon approach" to fight the so called "terrorists". To achieve this mission, US official beamed their searchlights on state where "terrorists" are suspected to reside or ones with records of being implicated in "terrorists" acts. Countries closely monitored include Afghanistan, Iraq, Iran, Syria, Palestine, Sudan and Somalia.

The Bush policies on war against "terrorism" are unclear in defining the position of the enemy. Generally, individual states re-engineered their national security policies in order to flush out "terrorists" or militants that disturb the peace of their territories. The essence of the anti "terrorists" campaign became the challenge for each state to provide security for itself and its citizens because security is the primary focus of any state.

A quest of national security led US and its allies to launch the first attack on the Taliban government of Afghanistan on October 7, 2001(Malkawi, 2001). The central goal of "Operation Enduring Freedom", the code given to the operation in Afghanistan, was the destruction of training camps and infrastructure within Afghanistan, and the capture of al-Qaeda and Taliban leaders. In the war, US-led counterterrorism efforts focused especially on the south-west Asia following its (US) identification of the region as threat to both regional stability and the attainment of key US policy goals (Kronstadt, 2003). Pre-emptive war was launched against Iraq because Saddam Hussein was accused of giving support to "terrorists".

To America, the decision to fight "terrorism" in the first place was a result of their military superiority. They removed the Taliban government of Afghanistan and Saddam Hussein of Iraq from power, and left both countries highly insecure.

The above statement explains to an extent the core reason while the aggression on the US - Iraq journalist resorted to shoe throwing at the visiting President Bush in Baghdad, probably wishing to actually kill him at spot and causing a big International embarrassment to the West.

Relatively, Abdallah (2003:1) asserts that "anti-America hatred is enflamed mainly by United States of America economical, political and military support for Israel, which has enabled it to defeat and humiliate the Arabs. Also he points to "US air strikes and sanctions against several Arab countries and its occupation of Iraq support for certain undemocratic Arab regimes, its military bases in a number of Arab countries.

The paper tend to view the action of the Iraqi journalist misplaced aggression on the US president from past American policies and to situate the action on insecurity in and around the state. The paper would be separated into four sections. The first treats the concept of aggression. The second section would approach Bush versus Muntadar al-zaidi - misplaced aggression in international relations. The third section would examine the issues in war against terrorism in Iraq and conclusion.

\section{Concept Of Aggression}

The concept of aggression in most cases dual on international use of armed force, blockage to access use of international waterway and so on that affect other state. In the past, aggression is viewed from state act or conduct against another state, even with the latter happening within and between the nations like Israel attack on the Gaza, Lebanon, Uganda- a rescue mission to save Israelites. In this contemporarily period scholars have start measuring aggression expansion beyond state in the range of non-actors capable of committing aggression like the Iraq journalist attack on President George W. Bush.

Consequently, the act of committing an aggression amount to an attack upon the state and this represent a particular type of political act which other personal conduct can be viewed. This action finds expression in the 
words of Stohl (2002), who explain that it is the US global hegemonic power within the international system, and western euro-centricity, which are the problems. That Mundatar argued was queried Bush foreign policy on Iraq which is President was in support of war on terror.

If the America government had gave up as the hurled shoes representing a missile in the occasion, would America has viewed it as a personal attack on their President, the answer is no, it would have been an aggression against the America state. In many occasion America has used all set down process to save their citizen from international humiliation. And they would have view the hurt on America President as a disgrace to the struggle that prone the America troop to enter Iraq to solve, and again a challenge to western values. Although states have a legal right to defend themselves against aggression, legal scholarship has not reached a consensus on when that right may be invoked (Kegley and Raymond, 2003).

Muntadar al-Zaidi's action can be viewed from the radical commentators as centred on aggression. In as much as an individual commit can act with State backing as the Libya officer that masterminded the Lockerbie's bombing. It has expression in the past, when weaker nations applied terrorism as a toll against the stronger states to express their grievances against control or influence within the confines of their national borders.

In the $21^{\text {st }}$ century, we may want to ask do we live in a world full of attack? Eric Froom explains that incidental violence arises out of action of protest or affirmation of certain views. This violent action can be rooted in hate and destructiveness ( Eric Froom, cited in Encarta 2008).

Hate and destructiveness are impulses which obscure rational and objectives thinking and easily create a polarization. Thomas Hobbes, Sigmund Freud, Konrad Lorenz and other scholars assumed that man is an inherently aggressive animal. A second view is that aggressiveness or destructiveness is not an instinct, nor is it inherent in human nature as such, but is rather acquire. The third view presented by Dollard is that aggression is always the result of frustration (Cited from Encarta 2008)

The Iraqi journalist was given the opportunity to cover news in the Bagdad conference felt the suffering of the Iraq people was singlehandedly cause by the Bush administration for tagging Iraq as a state that haven terrorists and as such there must be a regime change that finally ousts Saddam Hussein. On close range he went for retaliation to express his grievances. This plays down on article 2(4) of the UN's charter which encourages the principles of sovereign equality of states and non-interference.

\section{MISPLACED AGGRESSION: Bush versus Muntadar al-Zaidi, A Radical Perspective}

The radical analysts see aggression as manifest in such contentious issues as nationalistic, separatist, racist, religious, or ideological goals and effort to attain them through long periods of struggles. They argue that economic exploitation and political injustice in the society or state move individuals to be aggressive. Claude (1983: 4) explains that "the economic structure is autonomous and strictly determines the others". He explains further that "attitudes, beliefs, motivation and other forms of consciousness do not exist in a vacuum, nor are they mere accidents" (Claude, $1983: 8$ ) in doing this, whoever must have placed people like Muntadar al-Zaidi or their like to act in a form of change of good attitude to a bad one -such a state of deprivation are targeted recipients of their grievance. In law such as act is view as crime against humanity.

To some commentators on this issue of deprivation, it is the incursion of the US and her allies into oilproducing areas of the Middle East between the $19^{\text {th }}$ and $21^{\text {st }}$ centuries and the support puppet government, when oil has become a vital economic commodity, that sparked off grievances by Arab radicals. The US claimed that it could not fold its hands while some Arab radicals seen as members of "terrorist" groups threaten their interest and, by extension, their control of the area. In this sense, the US was driven by:

"trying to solve the Arab-Israeli conflict on the basis of UN Security Council resolution 242 and 338 for the past 30 years. It sponsored peace, treaties between Israel and both Egypt and Jordan and established military bases in some Arab countries to protect them. He further explain that Arab people saw all the above mentioned US actions as America efforts to protect Israel.

It is also true that America provides Egypt, Jordan, Morocco, Yemen and other Arab countries with Economic and military aid.

America fought Iraq in 1991 at the request of Kuwait and other countries and with the participation of forces from Egypt, Syria and GCC countries" (Abdallah 2003:2).

Arab regimes that serve American interest in the war against "terrorism" in Afghanistan and Iraq had fueled the hatred for America due to Bush not taken into account the interest of US citizen resident outside America.

Abdallah (2003) further explain that Arab people saw all the above mentioned US actions as America efforts to protect Israel, as well as some Arab regimes that serve America interest.

The non-recognition of Palestinian territory as a state, and the subsequent creation of the Jewish state called Israel in 1948, encouraged "terrorist" attacks on supporters of Israel, principally the US and its allies. The fight between these two neighbors-Israel and Palestine-caused an upsurge in refugee problems in Palestine, majority 
of the Arab states were against the new Israeli nation, leading to serious anti-Jewish riots in Yemen and Syria. The homelessness of Palestinians gave rise to the Palestinian Liberation Front, under the leadership of Late Yasser Arafat, to challenge their immediate enemy, Israel, and extend their attacks, through suicide missions, to US installations. Arafat in his understanding of the world terrorism never saw anything wrong with the damage caused by freedom fighters or "terrorist" as Western scholars termed them. Arafat maintained that the action put up by freedom fighters is justifiable. He declared, "He who fought for a just cause, he who fought for the liberation of his country, he who fought invasion and exploitation single-mindedly, can never be defined as a terrorist". ( )

The Palestinian refugee problem became a serious issue between the Arab states and the UN. The pains of refugee life engendered Arab "terrorism" which is now becoming a serious international concern. This explains why some parts of the Middle East challenge the western culture introduced in the region by such leaders as Ayatollah Kommenis in the 1980s which led to the emergence of grassroots people who radically opposed western values, especially US hegemony, Osama Bin laden (October 7, 2001) declared: "I swear to God that America will not live in peace unless peace reigns in Palestine, and all the army of infidels depart the land of Mohammed... "The land of Mohammed is Saudi Arabia. Put differently, the speech of Osama imbues radical Islamic militants or "terrorists" with the ability to challenge the hegemonic power of the US. In an earlier proclamation, Bin Laden (1998) had stated that "terrorism" is an expression to liberate the oppressed people, as is the case with Palestine. He argued that US and its allies are an "oppressive, corrupt and tyrannical regime". Therefore, according to him, "terrorism" is a justifiable tactic used against the powerful states as their presence has humiliated and incapacitated the Muslim people. He therefore proclaims total war against these oppressive powers through sporadic terrorist attacks. This is a remarkable shift from the position he held earlier when he played a principal role in Afghanistan-USSR war, with full American support. After the fight, Bin Laden and his group experienced a feeling of emptiness; where there was no longer any immediate enemy through which he could define both himself and his view of Islam. The fighting in Afghanistan had provided them with an identity, a group that functioned as a community. From the radical position mundatar-al-zaidi action was a sign of revenge on the image of the US on the invunrable Iraq that suppose to be safe on the attacks on terrorists that harboured among the people.

\section{War On Terror In Iraq}

The relationship between the US and Iraq can be viewed in phases. The first phase was an alliance in which the US supported Iraq in the war against Iran. In the Iraq-Iran war in the 1980s, the Americans enthusiastically supported Saddam Hussein. The Gulf War (1991) following Iraqi occupation of Kuwait marked the second phase and the beginning of hostilities between the US and Iraq. Eric Huskins (2002) informs that it "effectively terminated everything vital to human survival in Iraq, including electricity, water, sewage systems, agriculture industry and health care". The third phase is the Gulf War and its continuing impact significant among which being the US-sponsored low-intensity but high casualty campaign of economic sanctions conducted through the offices of the United Nations. Later resolution 986 (1995) introduced the oil-for-food programme, which did not bring much respite to Iraq's spiraling plight. The sanctions worsened the relationship between Iraq and the US. This sanction affect young children, many under five years age (Edward and Crowell 2002) and dropped Iraq's ranking in the UNDP Humanitarians Development Index from 96 in 1990 to 126 in 2000(Bossuyt 2000).

The Global War on Terrorism, GWT campaigns against Iraq appears to be the most controversial and a major threat to world peace. On the pretext of disarming Iraq of alleged Weapons of Mass Destruction (WMD), the US invaded Iraq, overthrew Saddam Hussein, its erstwhile leaders, and planted occupational forces to ensure peace in that country pending the formation of a new government. So there was no justification nor sustained sanctions against and punishment of Iraq. It undermined virtually every claim the Bush administration had made about Iraq's alleged weapon of mass destruction. Some commentators have argued that George W. Bush has allowed "emotionalism" to affect his professional and state duty. Besides, the invasion of Iraq tagged "Operation Iraqi Freedom" (2003) from the perspective of US-led coalition forces was informed partly by the need to free Iraqis from the dictatorial rule of Saddam Hussein and rid Middle East of gross human right abuse. Yet, one of the divergent views posits that America's invasion of Iraq is one of its series of hegemonic campaign. As the huge majorities in the Arab and Islamic worlds, France, Spain, Britain, Germany and Russia opposed the use of military force against Iraqi while many Arabs believe that the real intention behind the US occupation of Iraq is a desire to further Israel's security and oil supply (Abdallah 2003:2).

The September 11, 2001 (henceforth identified as 9/11) incidence in the US has its impact on international politics. It has engendered international conflicts with grave consequence. One of such consequences is that it has encouraged major power, especially the US, to label some countries haven of "terrorists" and security threat to world peace. 
If we critically examine the main factors in the US-Iraq war, they range from political, economic to the ideological. In the war between Iraq and Iran in the 1980's, Saddam Hussein had sought Iraq to replace Iran as the preponderant power in the Gulf and to replace Egypt as the leader of the Arab world. Of course Saddam failed in that enterprise (Robert Mandel 1998). Whenever and wherever there appears to be a major threat to its supremacy the US has always found justification to beam its searchlight on the area, and generate real or imagined propaganda to validate its quest to contain such a region or force (Robert Mandel 1998).

This conflict led to the deadliest month of war (April 2004) for both sides. About 1331 Iraqi civilians and 1000 insurgents were killed, while 136 troops die. US military commanders kept about 140,000 US troops in Iraq through 2005: Spain 1,300 troops: Bulgaria and Ukraine about 15000 troops. Other nation involved included Norway, Thailand and Japan with its 600 troops mostly engaged in humanitarian and non-combat duties.

Because US and British forces, amounting to 70,000 troops, played the principal combat role in Iraq, the departure of smaller forces was believed to have more of political than military impact.

According to the Iraqi study group, Joseph Stightz and Linda Blimes (2007). Iraq economy grew at rate of 4 percent, well below the target the target growth rate of 10 percent. The rate of inflation was more than 50 percent. Iraq went from producing 2.8 million barrels of oil a day to 1.8 million barrels a day in January 2006, as a result of guerilla war and pipeline sabotage. Later oil production climbed back to 2.2 million barrels per day, bur still below the government's goal of 2.5 million barrels. (Cole June 2007).

Currently the US and the entire occupation forces are facing two types of expressive violence: regime holdouts and score setting. Despite the rapid and comprehensive military defeat of the regime's Special Forces, the underground regime loyalists have waged an armed resistance against the occupation forces. A long tradition of conspiratorial politics involving the military, widespread ownership of small arms, and a political-tribal culture of setting scores by violence explains the episodic guerilla-style violence by those groups and individuals disenfranchised by the new status quo (Malik 2008).

Finally, limit of self-defence in the Article 51 of the UN charter recognizes that member states have the "inherent right of individual or collective self-defense if an armed attack occurs". The US and UK, in order to wage war on Iraq, gave three main argument: first, that the UN charter narrowly defines right of self-defense: second, the disputed customary international law gives the right of pre-emptive self defense, and lastly, the new and legally dubious doctrine of humanitarian intervention.

\section{Conclusion}

From the foregoing argument, there is strong dislike for America foreign policy in Iraq, and its allegedly in human treatment of terrorist prisoners, especially in camp X-ray the Guantanamo Bay detention centre in Cuba. The problem at the moment however is that the civil society is totally absent in Iraq and the voices of the people in Iraq is being represented by various resistance groups-Shias and Sunnis who are against the occupation forces.

The vulnerability calls for a reconsideration of the relationship between the Shia and the Sunni Moslems that dominate Iraq. The absence of this has caused more bloodshed and greatly held back present government from effectively running the apparatus of the state. The hatred was the action of Muntander al-Zadi and Iraqi journalist to hurl his shoe at the visiting US president. The action of the Iraq show thrower cannot be viewed as ordinary anger against the person of President Bush but the oppressive policies of past American leaders that Bush upheld. It is an expression of collective anger of the oppressed calling for change of American and Western policies towards the Middle East.

\section{The Way Forward}

To stop the violence in Iraq in particular and the Middle East in general, dangerous armaments supply links to each terrorist group must be investigated from the angle of the manufacturers of weapons and their vendors. The vendors are mainly interested in the money they make from hands of the "terrorists". Eradication of weaponry should be intensified in order to curtail human and property destruction.

Furthermore, we posited that anti-terrorism should be an exclusive responsibility of United Nations, irrespective of whether such attacks are domestic or international. This will deny states, weak or powerful, the ambition to single handedly fight global "terrorism". One of the approach would be a comprehensive strategy on fairness and equal opportunities for all.

\section{Reference}

[1]. Abdallah A.M.(2003) "Causes of Anti-Americanism in the Arab World. www.meria.idc.ac.il/journal/2003/issued4/jv7n4ab.html

[2]. Bush G (2002) The National Security for homeland security. http//www.whitehouse/book/nat-strat-h/s.pdf

[3]. Claude A. (1983) A Political Economy of Africa. Lagos: Longman Nigeria Limited.

[4]. Ibanga, M.(2002) The Terrorist Attacks on the United States and the right of self defence". The Calabar Law Journal volume vi-vii.

[5]. Khouri, N. (2002:2)cited from Toby Miller "Anti-Americanism and culture".www.tobymiller.org/images/culturalstudies/film/anti-america and culture.pdf.

[6]. Kronstadt K.A.(2003) International Terrorism in South Asia. Congressional Research order. Code RS21658. 
[7]. Kegley C.\& Raymond G.(2003) Preventive war and permissive normative order. International studies review, New York, vol 6, 2,

[8]. Makawi A (2001) Islamic view on Terrorism.mmalkawi@motorola.com

[9]. Karl Meyer (2004) America unlimited: The radical sources of the Bush doctrine. World policy.www.worldpolicy.org/journal/article/meyer.htm.

[10]. Mazrui A. (2002) Global Hostages: A new world order. http://www.ms.dk/sw8542.asp

[11]. Robert Mandel (1998). "Exploding myths about view/11694/12445

www.journals.hil.unb.ca/index.php/jes/article/view/1

[12]. Stohl, M.(2002) in Jabber, P.'Impact of the war on terror on certain aspects of US policy in the Middle East", prepared for National Intellengence Council in New York. 